Article

\title{
Distribution and Chemical Speciation of Molybdenum in River and Pond Sediments Affected by Mining Activity in Erdenet City, Mongolia
}

\author{
Tsetsgee Solongo ${ }^{1,2}$, Keisuke Fukushi ${ }^{3, *(1)}$, Ochir Altansukh 2 (1), Yoshio Takahashi ${ }^{4}$, \\ Akitoshi Akehi ${ }^{1}$, Gankhurel Baasansuren ${ }^{1}$, Yunden Ariuntungalag ${ }^{2}$, Odgerel Enkhjin ${ }^{2}$, \\ Boldbaatar Davaajargal ${ }^{2}$, Davaasuren Davaadorj ${ }^{5}$ and Noriko Hasebe ${ }^{3}$ \\ 1 Division of Global Environmental Science and Engineering, Graduate School of Natural Science and Technology, \\ Kanazawa University, Kanazawa, Ishikawa 920-1192, Japan; osko_8888@yahoo.com (T.S.); \\ akehimap@gmail.com (A.A.); baaska_0310@yahoo.com (G.B.) \\ 2 Department of Environment and Forest Engineering, School of Engineering and Applied Sciences, \\ National University of Mongolia, Ulaanbaatar 14201, Mongolia; altansukh22@yahoo.com (O.A.); \\ ariuna_0924@yahoo.com (Y.A.); unetbaigali@yahoo.com (O.E.); davkabold@yahoo.com (B.D.) \\ 3 Institute of Nature and Environmental Technology, Kanazawa University, Kanazawa, Ishikawa 920-1192, \\ Japan; hasebe@staff.kanazawa-u.ac.jp \\ 4 Department of Earth and Planetary Science, Graduate School of Science, The University of Tokyo, \\ Tokyo 113-0033, Japan; ytakaha@eps.s.u-tokyo.ac.jp \\ 5 Department of Geography, School of Art \& Sciences, The National University of Mongolia, \\ Ulaanbaatar 210646, Mongolia; davaadorjd@gmail.com \\ * Correspondence: fukushi@staff.kanazawa-u.ac.jp; Tel.: +81-76-264-6520
}

Received: 12 June 2018; Accepted: 26 June 2018; Published: 5 July 2018

\begin{abstract}
Rivers and ponds near the Erdenet mine, one of the world's largest copper-molybdenum mines, exhibit high concentrations of molybdenum (Mo). This study evaluates the distribution and chemical speciation of Mo in surface sediments from ponds and rivers in Erdenet city to elucidate the mobility and solubility of Mo in the surface aquatic environments in the area. The waters and sediments were collected in two shallow ponds connected to the tailing pond and from three rivers flowing through Erdenet city. The distribution and chemical speciation of Mo in the sediments were examined using five-step sequential extraction and X-ray absorption fine structure (XAFS) analyses. The XAFS spectra of the sediments showed that large amounts of Mo in the sediments are molybdate or polymeric molybdate, weakly adsorbed onto ferrihydrite. Sequential extraction consistently showed a large amount of Mo distributed in the labile fractions. Results suggest that the surface sediments from ponds and rivers play a role as secondary contamination sources of Mo rather than as sinks of Mo in the area.
\end{abstract}

Keywords: Erdenet mine; molybdenum; sediment; chemical speciation; XAFS; sequential extraction

\section{Introduction}

Mining activities are constantly contaminating surrounding aquatic environments such as rivers, ponds, and lakes by deposition of heavy metals and metalloids [1-3]. In Mongolia, the most important part of the economy is the mining sector. The International Monetary Fund (IMF) has estimated that about $71 \%$ of national income is earned from this sector [4]. One can readily expect that Mongolia has many active mine blocks. At Erdenet mine (Erdenet city, Mongolia), one of the largest $\mathrm{Cu}-\mathrm{Mo}$ mines in the world [5-7], mining wastes are disposed in a huge tailing pond that lies close to the Khangal River, 
flowing into Erdenet city [6]. Recent reports have described that the rivers affected by the seepage from this tailing pond contain high concentrations of molybdenum $[5,6]$.

Molybdenum (Mo) is an essential element for all living organisms with trace concentrations in natural surface waters ranging from $0.5 \mu \mathrm{g} / \mathrm{L}$ in streams to $10 \mu \mathrm{g} / \mathrm{L}$ in seawater [8]. However, the excesses in environmental Mo can cause functional enzymatic disequilibria [9]. The WHO drinking water guideline for Mo is less than $70 \mu \mathrm{g} / \mathrm{L}$ [10]. Recently, Smeldley and Kinniburgh [11] and Frascoli and Hudson-Edwards [12] review the Mo concentrations in mining-affected water, soils and sediments. The highest aqueous Mo concentrations are between 10,400 and 13,900 $\mu \mathrm{g} / \mathrm{L}$ from acid to alkaline mine drainage water at the San Telmo mine in the Spanish Iberian Pyrite Belt and at the Antamina mine in Peru $[13,14]$. The reported highest Mo concentrations in tailings impoundment channel waters are 2670-3900 $\mathrm{\mu g} / \mathrm{L}$ from Cu porphyry mines in the Machali Cachapoal Provcince, Chile [15]. The Mo concentrations in the mining-affected river water are $<0.3 \mu \mathrm{g} / \mathrm{L}$ from the Laver $\mathrm{Cu}-\mathrm{Ag}$-Au mine in Sweden and 0.6-9.7 $\mu \mathrm{g} / \mathrm{L}$ from the Gyama Cu-polymetallic mine in central Tibet [16,17]. The Mo contents in stream sediments and non-contaminated soils are typically around $10 \mathrm{mg} / \mathrm{kg}$ or less $[11,12]$. The highest Mo concentrations in the mine tailings are $4000 \mathrm{mg} / \mathrm{kg}$ from the Gyama Cu-polymetallic mine in central Tibet [17]. The highest Mo concentrations of the sediments is $1950 \mathrm{mg} / \mathrm{kg}$ from Surcheshmeh mine, Iran [18].

The dissolved heavy metals and metalloids in natural water commonly interact with minerals in soils and sediments $[2,19,20]$. The concentrations of the elements in natural water are usually controlled by interaction with minerals $[8,21]$. Therefore, understanding how Mo is sequestered by sediments and soils is crucially important for evaluating its mobility and solubility of Mo in natural water. The respective mobilities and solubilities of trace elements in soils and sediments depend mainly on the chemical speciation of the elements [22,23]. Strong chemical bonding of elements to mineral surfaces usually does not result in the release of the elements to natural water, while weak electrostatic bonding engenders the release of elements into the natural water [23,24]. Elements hosted in primary insoluble mineral phases or secondary insoluble phases are only slightly released to natural water, although those into soluble minerals are easily released during dissolution of the host phases [22,25].

Two important methodologies have been used to assess the chemical speciation of elements in natural solid samples. The first is the traditional sequential chemical extraction method [26,27]. Sequential extraction can show the quantitative partitioning of trace elements in constituents of soils and sediments. However, extraction reagents can extract not only the target materials but also the unexpected mineral phases. Favas et al. [28] applied the sequential extraction technique to the tailings and the soils from the Ervedosa mine in northeastern Portugal. They observed that most of Mo is associated with the easily- to moderately-reducible fractions and interpreted that metals are bound to $\mathrm{Fe}, \mathrm{Al}$ and $\mathrm{Mn}$ (oxy)hydroxides and ferric hydroxysulfates. The second method is sophisticated spectroscopy such as X-ray absorption fine structure spectroscopy (XAFS) [22,29]. This methodology enables the direct observation of the chemical speciation of target elements. However, applications of spectroscopic methods to the elements present in very trace amounts in the soils and sediments are difficult because of the method's high detection limits. Blanchard et al. analyzed the mine tailings of Mo from uranium mine in norther Saskatchewan, Canada, by means of XAFS [30]. They found that the tailings consisted primarily of $\mathrm{Mo}(\mathrm{VI})$ species: powellite $\left(\mathrm{CaMoO}_{4}\right)$, ferrimolybdeite $\left(\mathrm{Fe}_{2}\left(\mathrm{MoO}_{4}\right)_{3} \cdot 8 \mathrm{H}_{2} \mathrm{O}\right)$, and molybdate adsorbed on ferrihydrite as well as a minor concentrations of a Mo(IV) species in the form of molybdenite $\left(\mathrm{MoS}_{2}\right)$. They also showed that Mo concentrations in the porewater in the tailing sediments are controlled by the mineralogical compositions containing Mo.

The combination of the two methodologies must engender a better understanding of the chemical speciation of trace elements in natural samples. By application of the sequential extraction procedure and the X-ray absorption fine structure spectroscopy, this study aims to identify the chemical speciation of Mo present in surface sediment from rivers and ponds in Erdenet city, which is affected by mining activity. 


\section{Studied Area}

The study area is the third-largest city in Mongolia: Erdenet city in the northern part of Mongolia (Figure 1a) lies in a valley between the Selenge and Orkhon rivers. The Erdenet mine, fourth largest copper-molybdenum (Cu-Mo) mine in the world, has been active since 1978 [5-7]. The Erdenet mine possesses porphyry $\mathrm{Cu}$-Mo deposit, developed in a continent-continent arc collision zone, within the central Asian orogenic belt in the early to middle Triassic. The Erdenet ore-bearing porphyry complex was preceded by multistage gabbro-granitoid magmatism [7]. Molybdenite occurs in monomineralic veins and in finely laminated with massive quartz-molybdenite veins [31].

The vast tailing pond is located in north of Erdenet city (Figure 1b). The tailing dam repositories are a $5 \mathrm{~km}$ long dyke of standard design, of which $3 \mathrm{~km}$ are covered with water and $2 \mathrm{~km}$ are exposed tailing beaches. The dam contains 400 million tons of mine tailings, as well as 15 million $\mathrm{m}^{3}$ of supernatant water [4]. The mining slags have been transported with wastewater to the tailing pond through the pipeline from the refinery factory. The slags have been settled down in the tailing pond. Some of the wastewater is evaporated from the surface of the tailing pond, and some of it is pumped to the refinery factory for re-use. Moreover, some of the wastewater is penetrated the bottom of the pond, and makes runoff through the sub-surface, and released as seepage in a southward of the pond, where is close to the Khangal River. The mining company had built secondary ponds to interrupt the flow of seepage water to the Khangal River. However, the seepage water, which is temporary stored in the secondary ponds, flows to the Khangal River, continuously. There are three rivers in Erdenet city: Erdenet River, Gavil River and Khangal River (Figure 1b,c). The Erdenet River flows from the west of the city. Gavil River flows from the north of the city. These two tributaries join to become the Khangal River, which flows to the east of the city. Their junction point is surrounded by a densely populated ger district, an agricultural area, and the tailing pond.
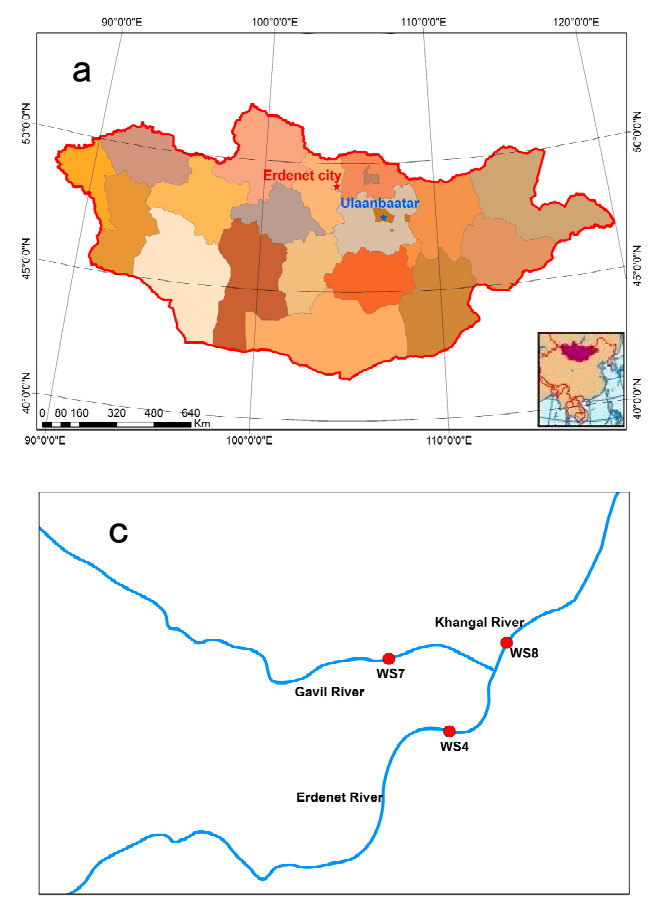

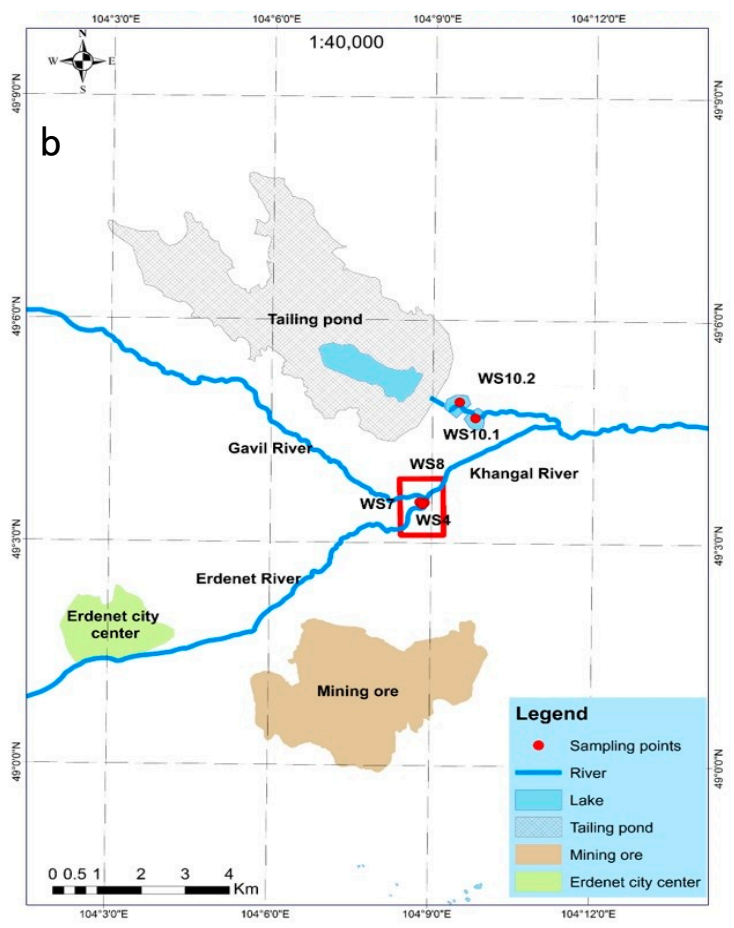

Figure 1. Study area with sampling locations: (a) Erdenet mine in Mongolia, (b) Erdenet mining area with sampling locations, and (c) the junction of the three rivers with sampling locations. 


\section{Materials and Methods}

\subsection{Sampling Sites}

The surface water $(\mathrm{W})$ and sediment $(\mathrm{S})$ samples were collected from the ponds and rivers in March 2017. Two pond samples, WS10.1 (49 $\left.04^{\prime} 41.21^{\prime \prime} \mathrm{N}, 104^{\circ} 09^{\prime} 48.03^{\prime \prime} \mathrm{E}\right)$ and WS10.2 ( $49^{\circ} 04^{\prime} 48.86^{\prime \prime} \mathrm{N}$, $104^{\circ} 09^{\prime} 30.45^{\prime \prime} \mathrm{E}$ ), were collected from the two secondary ponds connected to the big tailing ponds. As shown in Figure 1b, the seepage water flows between the tailing pond and the secondary ponds. The three river samples were collected at the junction point (Figure 1c). They are downstream of the Gavil River (WS7: $49^{\circ} 03^{\prime} 22.27^{\prime \prime} \mathrm{N}, 104^{\circ} 08^{\prime} 48.75^{\prime \prime} \mathrm{E}$ ), downstream of the Erdenet River (WS4: $49^{\circ} 03^{\prime} 33.49^{\prime \prime} \mathrm{N}, 104^{\circ} 08^{\prime} 46.88^{\prime \prime} \mathrm{E}$ ), and upstream of the Khangal River (WS8: $49^{\circ} 03^{\prime} 33.40^{\prime \prime} \mathrm{N}$, $104^{\circ} 08^{\prime} 48.01^{\prime \prime}$ E). The water and sediments were separately collected at same locations by using a plastic ladle with adjustable rods from the bank of the rivers or the border of ponds. We collected the surface sediments that are expected to be contacted with the surface water in the shallow ponds and rivers. The volume of the plastic ladle is $500 \mathrm{~mL}$. The depth of collected sediments were no deeper than $10 \mathrm{~cm}$ from the surface of the sediments. The obtained sediment samples were stored in the plastic bags with zips. The remained waters in the plastic bags were removed as much as possible.

\subsection{Water Analysis}

Temperature, $\mathrm{pH}$, electrical conductivity (EC), dissolved oxygen (DO), and oxidation reduction potential (ORP) were measured on site using EC, $\mathrm{pH}$, and ORP meters with electrodes (portable electrical conductivity pH meters, WM-32EP; TOA-DKK Corp., Tokyo, Japan) and a DO meter (DO-3IP; TOA-DKK Corp., Tokyo, Japan). Before the measurements, the $\mathrm{pH}$ electrode was calibrated with three $\mathrm{pH}$ buffer solutions ( $\mathrm{pH} 4.01,6.86$ and 9.18 at $25{ }^{\circ} \mathrm{C}$ ). Alkalinity of filtered solution with $0.45 \mu \mathrm{m}$ membrane was measured by titration with sulfuric acid $\left(\mathrm{H}_{2} \mathrm{SO}_{4}\right)$. After the water samples were filtered using a $0.45 \mu \mathrm{m}$ membrane cellulose filter to remove suspended particles, they were stored in two $50 \mathrm{~mL}$ plastic bottles that had been washed with diluted nitric acid and rinsed with deionized water before use. A small amount of ultra-pure grade nitric acid $\left(\mathrm{HNO}_{3}\right)$ was added to one bottle to make $0.6 \% \mathrm{HNO}_{3}$ for measurements of metals and silicon. Another bottle was left for major anion measurements.

The Mo and $\mathrm{Cu}$ concentrations in sample water were analyzed using an inductively coupled plasma-mass spectrometer (ICP-MS: X7; Thermo Inc., Waltham, MA, USA). The detection limit of $\mathrm{Cu}$ and $\mathrm{Mo}$ in this study was $100 \mathrm{ng} / \mathrm{L}$. Metal concentrations for $\mathrm{Na}, \mathrm{K}, \mathrm{Ca}, \mathrm{Mg}, \mathrm{Fe}, \mathrm{Mn}$ and $\mathrm{Si}$ were analyzed using inductively coupled plasma-optical emission spectroscopy (ICP-OES: ES-710; Varian Inc., Palo Alto, CA, USA). Anions for $\mathrm{Cl}^{-}, \mathrm{NO}_{2}{ }^{-}, \mathrm{NO}_{3}{ }^{-}, \mathrm{Br}^{-}$and $\mathrm{SO}_{4}{ }^{2-}$ were analyzed using high-performance liquid chromatography (8020 Series; Tosoh Corp., Tokyo, Japan).

\subsection{Sediment Analysis}

Equipment and supplies to collect sediments were cleaned by the deionized water and rinsed by site water at least three times prior to use. The sediment samples in the air-tight plastic bags were stored in refrigerator $\left(<10^{\circ} \mathrm{C}\right)$ in laboratory at National University of Mongolia for two weeks before transport to Japan. After the transportation to Japan, the sediment samples were again stored in refrigerator $\left(2-4{ }^{\circ} \mathrm{C}\right)$ in laboratory at Kanazawa University. The sediment samples were freeze dried (FDU-1200; EYELA Inc., Tokyo, Japan) in the laboratory after removal of stone and plant fragments. The dried sediments were sieved through a $64 \mu \mathrm{m}$ sieve. The obtained samples were stored in desiccator and used for chemical and mineralogical analyses.

\subsubsection{Sequential Extraction}

All reagents used were analytical grade. $\mathrm{HNO}_{3}$ used as a matrix of the ICP-MS and ICP-OES measurements was ultra-pure grade. Five-step sequential extraction was applied to elucidate the partitioning of Mo in the sediments (Table 1). The sequential extraction applied in the present study 
was based on the modified BCR (Community Bureau of Reference) extraction procedure for the analyses of heavy metals in soil proposed by Žemberyová et al. [27]. On the other hand, there is no extraction step specifically for the low crystalline oxides in the modified BCR extraction procedure. It is well documented that the low crystalline Fe and Mn oxides are good adsorbents for Mo [32]. Therefore, present study modified the method to include the extraction step for low crystalline oxides by using $\mathrm{pH} 3$ oxalate solution [33]. At the first step in the modified BCR procedure, $0.11 \mathrm{~mol} / \mathrm{L}$ acetic acid is used for the dissolution of carbonates and exchangeable metals. However, the $\mathrm{pH}$ of $0.11 \mathrm{~mol} / \mathrm{L}$ acetic acid is less than 3, which results in the dissolution of low crystalline iron oxides [33]. The sodium acetate solution adjusted to $\mathrm{pH} 5$ can only dissolve carbonate but low crystalline iron oxides [26]. Therefore, we used $\mathrm{pH} 5$ sodium acetate solution instead of $\mathrm{pH} 3$ acetic acid. Then we add the $\mathrm{pH} 3$ oxalate solution for extraction of low crystalline oxide prior to the hydroxylamine hydrochloride in the modified BCR procedure.

The target of the first step (F1) was Mo partitioning in exchangeable (weakly adsorbed) and carbonate (soluble at $\mathrm{pH}$ 5) from the bulk sample. $50 \mathrm{mg}$ sediment powder samples were treated at room temperature for $15 \mathrm{~h}$ with $20 \mathrm{~mL}$ of $1 \mathrm{~mol} / \mathrm{L}$ sodium acetate adjusted at $\mathrm{pH} 5 \mathrm{using}$ acetic acid on mixed-rotor [26]. The target of the second step (F2) was Mo partitioning in poorly crystalline iron and manganese oxides (soluble at $\mathrm{pH} 3$ under reducing condition). The residue from F1 was extracted with $20 \mathrm{~mL}$ of mixed solution of $0.2 \mathrm{M}$ ammonium oxalate solution adjusted at $\mathrm{pH} 3$ by oxalate for $4 \mathrm{~h}$ at room temperature on mix-rotor $[2,26,33]$. The target of the third step (F3) was Mo partitioning in crystalline Fe and Mn oxide (soluble at $\mathrm{pH} 2$ under strongly reducing condition). The residue from F2 was treated with $20 \mathrm{~mL}$ of $0.5 \mathrm{~mol} / \mathrm{L}$ hydroxylamine hydrochloride adjusted to $\mathrm{pH} 2 \mathrm{by} 2 \mathrm{~mol} / \mathrm{L}$ $\mathrm{HNO}_{3}$ at room temperature for $16 \mathrm{~h}$ on mixed-rotor $[27,34]$. The target of the fourth step (F4) was Mo partitioning in organic matter and sulfide minerals (soluble at highly oxidizing condition). The residue from $\mathrm{F} 3$ was treated further for $1 \mathrm{~h}$ at room temperature with $10 \mathrm{~mL}$ of $8.8 \mathrm{~mol} / \mathrm{L}$ hydrogen peroxide on mixed-rotor $[27,34]$. The vessels were heated at $85^{\circ} \mathrm{C}$ until the volume decreased to less than $3 \mathrm{~mL}$. After the second $10 \mathrm{~mL}$ of hydrogen peroxide was added to the vessels and heated again to dry at $85^{\circ} \mathrm{C}, 20 \mathrm{~mL}$ of $1 \mathrm{~mol} / \mathrm{L}$ ammonium acetate adjusted to $\mathrm{pH} 2$ with $\mathrm{HNO}_{3}$ was added to the residue for $16 \mathrm{~h}$ on mixed rotor. The target of the fifth step (F5) was Mo partitioning in the residues. The residue from $\mathrm{F} 4$ was digested completely in $3 \mathrm{~mL}$ of $48 \% \mathrm{HF}$ with $3 \mathrm{~mL}$ of $60 \%$ of $\mathrm{HNO}_{3}$ and was heated at $120{ }^{\circ} \mathrm{C}$ for $24 \mathrm{~h}$. Then $3 \mathrm{~mL}$ of $30 \%$ hydrochloric acid $(\mathrm{HCl})$ was added to the vessels and heated at $120{ }^{\circ} \mathrm{C}$ for $24 \mathrm{~h}$ to dry. The residues in vessels were extracted using $0.6 \% \mathrm{HNO}_{3}$. The obtained extracted solutions were diluted adequately using $0.6 \% \mathrm{HNO}_{3}$ solutions and were analyzed using ICP-MS for Mo and ICP-OES for $\mathrm{Mg}, \mathrm{Ca}, \mathrm{Fe}$, and Mn. We conducted the sequential extraction for the duplicated samples to check the reproducibility.

Table 1. Sequential extraction scheme in present study.

\begin{tabular}{|c|c|c|c|}
\hline Extraction Steps & Reagents & Temp. & Targets \\
\hline Fraction 1 & $\begin{array}{c}\mathrm{CH}_{3} \mathrm{COONa} \cdot 3 \mathrm{H}_{2} \mathrm{O}(1 \mathrm{~mol} / \mathrm{L}) \\
\text { with } \mathrm{CH}_{3} \mathrm{COOH} \text { at pH } 5\end{array}$ & \multirow{3}{*}{ Room Temp. } & Exchangeable $\mathrm{Ca}$ and $\mathrm{Mg}$ carbonates \\
\hline Fraction 2 & $\begin{array}{c}\mathrm{C}_{2} \mathrm{H}_{8} \mathrm{~N}_{2} \mathrm{O}_{4}(0.2 \mathrm{~mol} / \mathrm{L}) \\
\text { with } \mathrm{C}_{2} \mathrm{H}_{2} \mathrm{O}_{4} \text { at pH } 3\end{array}$ & & Low crystalline Fe and Mn oxides \\
\hline Fraction 3 & $\begin{array}{c}\mathrm{NH}_{2} \mathrm{OH} \cdot \mathrm{HCl}(0.5 \mathrm{~mol} / \mathrm{L}) \\
\text { with } \mathrm{HNO}_{3} \text { at pH } 2\end{array}$ & & Crystalline Fe and Mn oxides \\
\hline Fraction 4 & $\begin{array}{c}\mathrm{H}_{2} \mathrm{O}_{2}(8.8 \mathrm{~mol} / \mathrm{L}), \mathrm{CH}_{3} \mathrm{COONH}_{4}(1 \mathrm{~mol} / \mathrm{L}) \\
\text { with } \mathrm{HNO}_{3} \text { at pH } 2\end{array}$ & $85^{\circ} \mathrm{C}$ & Organic matter and sulfides \\
\hline Fraction 5 & $\mathrm{HF}(48 \%)$ with $\mathrm{HNO}_{3} 60 \%, \mathrm{HCl}(30 \%)$ & $120^{\circ} \mathrm{C}$ & Residues \\
\hline
\end{tabular}

\subsubsection{X-ray Diffraction}

X-ray diffraction (XRD) patterns for the sieved sediment samples were obtained using an X-ray diffractometer (Ultima IV; Rigaku Corp., Tokyo Japan) with monochromatic $\mathrm{Cu}$ K $\alpha$ radiation operated at $30 \mathrm{kV}$ and $20 \mathrm{~mA}$ from $2^{\circ}$ to $65^{\circ}$. The step size was $0.02^{\circ}$. The scan speed was $1^{\circ} / \mathrm{min}$. 


\subsubsection{X-ray Absorption Fine Structure}

Molybdenum K-edge XAFS spectra were obtained in the beamline BL01B1 of SPring-8 (Hyogo, Japan). The white beam from a bending magnet was monochromatized using a $\mathrm{Si}(111)$ double-crystal monochromator. The K-edge XAFS spectra for the natural samples were measured in fluorescence mode using a 19-element Ge solid-state detector, although those for reference materials were measured in transmission mode. The measurements were conducted under ambient conditions. The X-ray energy was calibrated with the first peak of Mo metal foil at $20.004 \mathrm{keV}$. The $\mathrm{MoO}_{4}{ }^{2-}$ solution, heptamolybdate solution, $\mathrm{MoO}_{2}, \mathrm{MoS}_{2}$, and $\left(\mathrm{NH}_{4}\right)_{2} \mathrm{MoS}_{4}$ were used as reference materials. The $\mathrm{MoO}_{4}{ }^{2-}$ solution was prepared by dissolving $\mathrm{Na}_{2} \mathrm{MoO}_{4} \cdot 2 \mathrm{H}_{2} \mathrm{O}$ (Wako Pure Chemical Inds. Ltd., Osaka, Japan) into Milli-Q (MQ) water and adjusting it to $0.10 \mathrm{M}$. The heptamolybdate solution $(0.10 \mathrm{M}$ as $\mathrm{Mo})$ was prepared by the dissolution of ammonium heptamolybdate tetrahydrate, $\left(\mathrm{NH}_{4}\right)_{6} \mathrm{Mo}_{7} \mathrm{O}_{24} \cdot 4 \mathrm{H}_{2} \mathrm{O}$ (Wako, Osaka, Japan) into MQ water. The pellets of $\mathrm{MoO}_{2},\left(\mathrm{NH}_{4}\right)_{2} \mathrm{MoS}_{4}$ (Wako, Osaka, Japan), $\left(\mathrm{NH}_{4}\right)_{6} \mathrm{Mo}_{7} \mathrm{O}_{24} \cdot 4 \mathrm{H}_{2} \mathrm{O}$, and $\mathrm{Na}_{2} \mathrm{MoO}_{4} \cdot 2 \mathrm{H}_{2} \mathrm{O}$ were made by dilution with boron nitride (BN) to $10 \mathrm{wt} \%$. The $\mathrm{MoO}_{4}{ }^{2-}$ sorbed $\mathrm{Mn}$ and $\mathrm{Fe}$ oxide were synthesized in the laboratory as reference materials. The preparation of $\mathrm{MoO}_{4}{ }^{2-}$-sorbed $\mathrm{Fe}$ and $\mathrm{Mn}$ oxides was described by Kashiwabara et al. [32]. The spectra obtained from Kashiwabara et al. [32] were used as standards for this study. The $\mathrm{MoO}_{4}{ }^{2-}$ solution, $\mathrm{MoO}_{4}{ }^{2-}$-sorbed $\mathrm{Fe}$ and $\mathrm{Mn}$ oxides and heptamolybdate solution are $\mathrm{Mo}(\mathrm{VI})$ species while $\mathrm{MoO}_{2}, \mathrm{MoS}_{2}$, and $\left(\mathrm{NH}_{4}\right)_{2} \mathrm{MoS}_{4}$ are $\mathrm{Mo}(\mathrm{IV})$ species.

Extended X-ray absorption fine structure (EXAFS) analysis was performed using software (REX2000; Rigaku Corp., Tokyo, Japan) with theoretical backscattering amplitudes and phase-shift functions obtained using FEFF 8.5 [35]. The Fourier transformation of the $k^{3} \chi(k)$ oscillation from $k$ space to $R$ space was performed in the range of 3.0-13.25 $\AA^{-1}$ to obtain radial structural functions (RSFs) for Mo. The quality of fit was given by the goodness of fit parameter. Details of the experiments and fitting procedure were presented by Kashiwabara et al. [32].

\section{Results}

\subsection{Water Chemistry}

Table 2 shows the water chemistries from the rivers (W4, Erdenet River; W7, Gavil River and W8, Khangal River) and pond (W10.1 and W10.2) samples. The water chemistry of the Erdenet River (W4) resembled that of the Khangal River (W8) but differed from that of the Gavil River (W7). Although the Erdenet River and Gavil River join to form the Khangal River (Figure 1c), the contribution of the Gavil River to the Khangal River might be minor compared to that of the Erdenet River. The Erdenet River (W4) and the Khangal River were characterized as having neutral $\mathrm{pH}$ and low EC values. The $\mathrm{Ca}^{2+}$ and $\mathrm{SO}_{4}{ }^{2-}$ concentrations are lower than those of the Gavil River. The $\mathrm{pH}$ and $\mathrm{HCO}_{3}{ }^{-}$concentrations of the Gavil River are markedly higher than those of other samples. Secondary ponds exhibited lower $\mathrm{pH}$ and alkalinity $\left(\mathrm{HCO}_{3}{ }^{-}\right.$concentrations) but higher $\mathrm{EC}$ values and $\mathrm{SO}_{4}{ }^{2-}$ concentrations than the rivers. The $\mathrm{NO}_{3}{ }^{-}$concentrations of secondary ponds were significantly lower than those of the rivers. Among the samples, EC values were correlated positively with $\mathrm{SO}_{4}{ }^{2-}$ concentrations, while $\mathrm{pH}$ was correlated with $\mathrm{HCO}_{3}{ }^{-}$concentrations. The Mo concentrations of the secondary ponds exceeded $700 \mu \mathrm{g} / \mathrm{L}$. That of the Gavil River is lowest $(8 \mu \mathrm{g} / \mathrm{L})$ among the samples. The Erdenet River and Khangal River show mutually similar Mo concentration of around $25 \mu \mathrm{g} / \mathrm{L}$. The $\mathrm{Cu}$ concentrations of all samples were lower than $10 \mu \mathrm{g} / \mathrm{L}$. 
Table 2. Water chemistries from river (W4, Erdenet River; W7, Gavil River; and W8, Khangal River) and pond (W10.1 and W10.2) samples.

\begin{tabular}{clccccc}
\hline & & W4 & W7 & W8 & W10.1 & W10.2 \\
\hline $\mathrm{T}$ & ${ }^{\circ} \mathrm{C}$ & 1.5 & 1.3 & 3.1 & 1.2 & 6.8 \\
$\mathrm{pH}$ & $(-)$ & 7.4 & 8.2 & 7.3 & 7.1 & 6.7 \\
$\mathrm{ORP}$ & $\mathrm{mV}$ & 200 & 180 & 180 & 170 & 230 \\
$\mathrm{EC}$ & $\mathrm{mS} / \mathrm{m}$ & 100 & 160 & 110 & 200 & 220 \\
$\mathrm{DO}$ & $\mathrm{mg} / \mathrm{L}$ & 7.5 & 6.5 & 7.7 & 5.1 & 2.3 \\
$\mathrm{Na}^{+}$ & $\mathrm{mg} / \mathrm{L}$ & 54 & 54 & 55 & 140 & 95 \\
$\mathrm{~K}^{+}$ & $\mathrm{mg} / \mathrm{L}$ & 2.4 & 20 & 3.9 & 4.6 & 2.1 \\
$\mathrm{Mg}^{2+}$ & $\mathrm{mg} / \mathrm{L}$ & 43 & 79 & 46 & 94 & 83 \\
$\mathrm{Ca}^{2+}$ & $\mathrm{mg} / \mathrm{L}$ & 100 & 180 & 110 & 300 & 260 \\
$\mathrm{SO}_{4}{ }^{2-}$ & $\mathrm{mg} / \mathrm{L}$ & 250 & 320 & 250 & 880 & 900 \\
$\mathrm{Alkalinity}^{-}$ & $\mathrm{meq} / \mathrm{L}$ & 4.4 & 5.8 & 3.4 & 2.9 & 3.1 \\
$\mathrm{NO}_{2}{ }^{-}$ & $\mathrm{mg} / \mathrm{L}$ & 7.4 & 8.7 & 7.0 & 9.0 & 6.5 \\
$\mathrm{NO}_{3}{ }^{-}$ & $\mathrm{mg} / \mathrm{L}$ & 24 & 24 & 24 & 1.7 & $<1$ \\
$\mathrm{Si}$ & $\mathrm{mg} / \mathrm{L}$ & 8.1 & 11 & 8.3 & 8.2 & 8.1 \\
$\mathrm{Cl}{ }^{-}$ & $\mathrm{mg} / \mathrm{L}$ & 23 & 29 & 26 & 36 & 33 \\
$\mathrm{Fe}$ & $\mathrm{mg} / \mathrm{L}$ & $<0.5$ & $<0.5$ & $<0.5$ & $<0.5$ & $<0.5$ \\
$\mathrm{Mn}$ & $\mathrm{mg} / \mathrm{L}$ & $<0.5$ & $<0.5$ & $<0.5$ & $<0.5$ & $<0.5$ \\
$\mathrm{Cu}$ & $\mu \mathrm{g} / \mathrm{L}$ & $<10$ & $<10$ & $<10$ & $<10$ & $<10$ \\
$\mathrm{Mo}$ & $\mu \mathrm{gg} / \mathrm{L}$ & 27 & 7.6 & 24 & 780 & 1500 \\
\hline
\end{tabular}

\section{2. $X R D$}

The crystalline mineral assemblages are quartz, calcite, chlorite, mica, plagioclase, and amphibole (Figure A1). Minerals with high intensities are quartz and plagioclase. All samples contain quartz, plagioclase, mica, and chlorite. S4, S7 and S10.1 also contain amphibole, although S8 and S10.2 does not contain it. Calcite was detected from S4, S7, and S10.1 but not from S8 or S10.2. Peak intensities of quartz of S10.2 were found to be the highest among the samples.

\subsection{Sequential Extraction}

Analytical chemical extraction has been applied to understand the partitioning of Mo into five extractions: exchangeable (weakly adsorbed) and $\mathrm{Ca}$ and $\mathrm{Mg}$ carbonates (F1), amorphous Fe and Mn oxides (F2), reducible Fe and Mn oxides (F3), oxidizable (organic matter and sulfides) (F4) and residual (F5). $\mathrm{Ca}, \mathrm{Mg}, \mathrm{Fe}$, and $\mathrm{Mn}$ are the important elements which constitute the target minerals in F1, F2, and F3. These elements were measured in each extraction. We conducted the duplicate sequential extraction analyses. Both results are similar (Table A1). Therefore, the elements concentrations are given as the average of two measurements.

Highest total Mo content $(1100 \mathrm{mg} / \mathrm{kg})$ was observed from the pond sediment sample $\mathrm{S} 10.2$ (Figure 2a and Table A1). The Mo in S10.2 dominated in F1 $(600 \mathrm{mg} / \mathrm{kg})$, followed by F2 $(200 \mathrm{mg} / \mathrm{kg})$, F4 $(160 \mathrm{mg} / \mathrm{kg})$ and F5 $(50 \mathrm{mg} / \mathrm{kg})$. The contributions from F3 were negligible. The Mo contents $(70 \mathrm{mg} / \mathrm{kg})$ of S10.1 are significantly lower than S10.2, although S10.1 also came from the pond sediment connected to the vast tailing pond. The Mo in S10.1 dominated in F2 $(50 \mathrm{mg} / \mathrm{kg})$, following by F5 $(20 \mathrm{mg} / \mathrm{kg})$ and F1 $(7 \mathrm{mg} / \mathrm{kg})$. Contributions from F3 and F4 were negligible. The Mo contents and the distributed fraction of S7 (Gavil River sediment) was comparable to S8 (Khangal River). The total Mo contents were around $30 \mathrm{mg} / \mathrm{kg}$. The Mo mainly distributed into F1, F2 and F5. The lowest Mo content in the Erdenet River sediment was less than detection limits from each step $(<4 \mathrm{mg} / \mathrm{kg})$. Among all samples except for S4, most Mo is distributed in F1, F2, and F5. Mo in F3 and F4 are minor, except for F4 from S10.2.

Among the sediments, the distributions of Fe and Mg dominated in F5 (Figure 2b,c, and Table A1). Fe in F5 fraction was well correlated with Mg. Mica, chlorite and amphibole detected from the XRD patterns usually contain Fe and $\mathrm{Mg}$ in their structures [36,37]. Fe and $\mathrm{Mg}$ in F5 are attributable to 
the clay minerals and amphibole. However, the second important Fe was in F2, and Mg was in F1. The Fe in F2 is most likely attributable to low crystalline Fe oxides (ferrihydrite), which cannot be detected by XRD because of their low crystallinity [38]. Fe in F2 ranges from 0.2 to 1.3 wt \% among samples. S10.1 sediment exhibited the highest Fe concentration (1.3 wt \%) in F2. Calcite commonly contains $\mathrm{Mg}$ in the Ca sites in the structure [39]. Therefore, $\mathrm{Mg}$ in F1 must be attributable to calcite. The extracted behaviors of $\mathrm{Ca}$ differed from Fe and $\mathrm{Mg}$ (Figure $2 \mathrm{~d}$ and Table A1). The contributions of F1 in Ca were comparable to those in F5, although those of other fractions (F2, F3, and F4) were minor. S7 and S10.1 exhibit the higher Ca concentrations in F1 at around 3 wt \%, although S10.2 exhibited the lowest concentrations at around $0.2 \mathrm{wt} \%$. The calcite peaks were not detected from XRD patterns of S8 and S10.2 (Figure A1). The variation in Ca amount from F1 among the samples is consistent with the abundances of calcite in XRD analyses. The total amounts of Mn were lower than other major elements (Fe, $\mathrm{Ca}$ and $\mathrm{Mg}$ ), with ranges from $0.08 \mathrm{wt} \%$ to $0.3 \mathrm{wt} \%$ (Figure 2e and Table A1). Mn dominates in F2 and F5, but the contribution of F1 was also important. F2 was more important for the river sediments (S4, S7 and S8). The total measured major element ( $\mathrm{Mg}$, Ca and Fe) concentrations of S10.2 were markedly lower than those of other samples, which suggests that the chemical composition of S10.2 dominates $\mathrm{SiO}_{2}$ as was supported from XRD result.
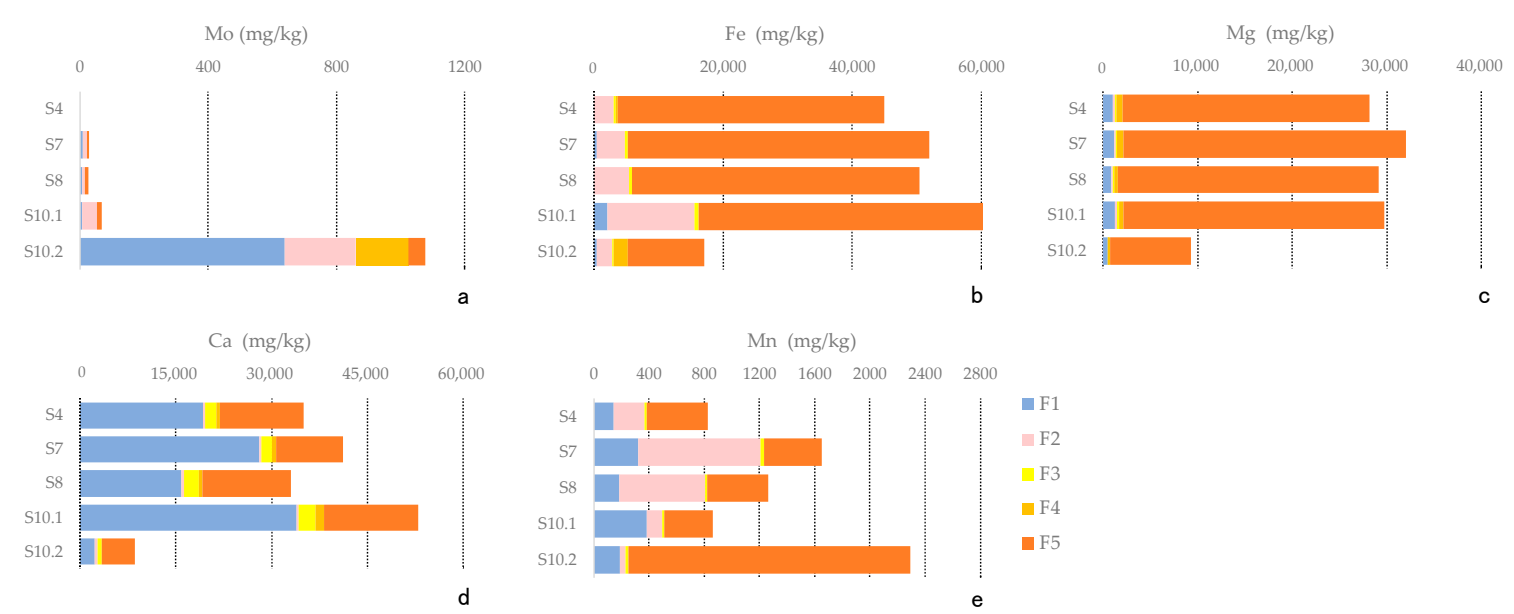

Figure 2. Results of the sequential extraction of river (S4, Erdenet River; S7, Gavil River; and S8, Khangal River) and pond (S10.1 and S10.2) sediment samples for Mo (a), Fe (b), Mg (c), Ca (d), and Mn (e).

\subsection{XAFS}

Figure 3 portrays EXAFS spectra in $k$ and $R$ spaces for the $S 10.2$ sample and the reference materials. The Mo contents of other samples (S4, S7, S8 and S10.1) are too low (less than $100 \mathrm{mg} / \mathrm{kg}$ ) to elicit reliable spectra. The EXAFS spectra provide information related to the coordination environment of the Mo species in S10.2. The RSF of S10.2 exhibits a prominent peak because of Mo-O at $R+\Delta R=1.1 \AA$ with a shoulder at $1.7 \AA$ suggesting that multiple Mo-O shells are present for Mo in S10.2. No evidence exists of the presence of Mo-S bonding in the sample because of the lack of Mo-S shells, which will also be confirmed by X-ray absorption near edge structure (XANES) (Figure 4). The Mo-O peak in the $R$-range of $0.65-2.05 \AA$ was fitted well by three Mo-O shells at distances of $1.72 \AA$ (coordination number (CN): 2.3), $1.91 \AA$ (CN: 0.61), and 2.11 $\AA$ (CN: 1.3), where the respective errors of the distance and $\mathrm{CN}$ are $0.02 \AA$ and $20 \%$ [40]. They are possibly ascribed to a mixture of various Mo-O species in molybdate ion (Mo-O distance: $1.77 \AA$ [41]), heptamolybdate (Mo-O distance: 1.70-1.97 $\AA$ [42]), and $\mathrm{MoO}_{2}$ (Mo-O distance: 1.95-2.07 $\AA$ [43]). Although the specific mineral phases containing Mo cannot be ascertained solely from this information, molybdate and heptamolybdate can be formed by the dissolution of Mo into water, which can subsequently be adsorbed or incorporated into secondary phases during solid-water interactions. In particular, molybdate ion is adsorbed on ferrihydrite by forming outer-sphere complex, which leads to the similar spectra of hydrated molybdate ion and that 
adsorbed on ferrihydrite [32]. $\mathrm{MoO}_{2}$ species can be present in the solid phase, which is not related to the solid-water interactions, in particular for the samples formed under oxic conditions for the samples in this study.

(A)

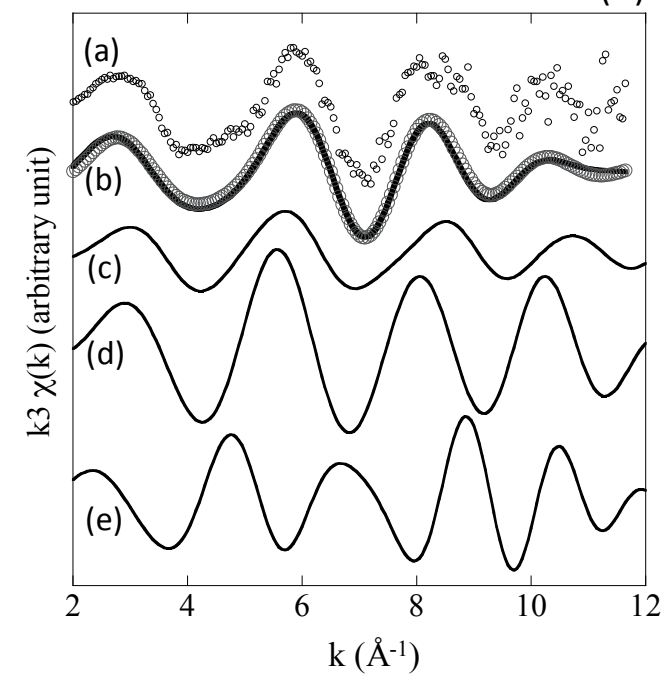

(B)

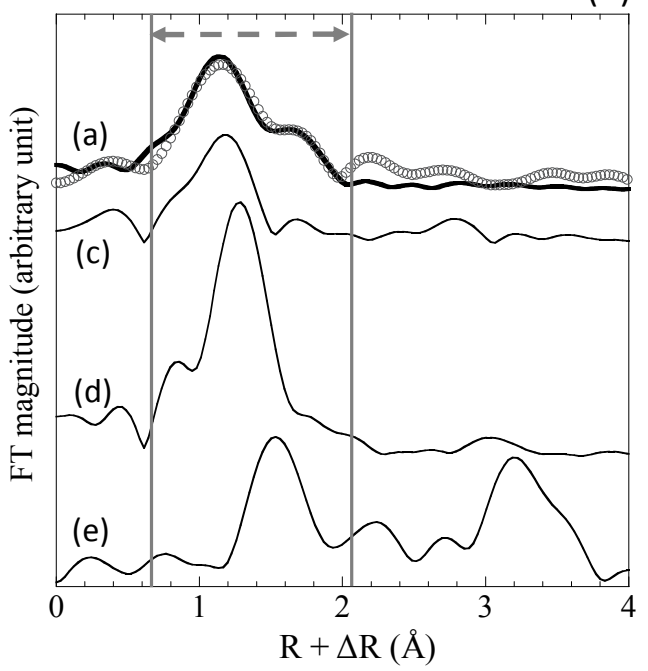

Figure 3. Mo K-edge EXAFS spectra in (A) $k$ and (B) $R$ spaces for S10.2 and related reference materials. Spectra (a) in $k$ and $R$ spaces are presented as small circles for S10.2. Fitting of the spectrum (a) in $R$ space by assuming Mo-O shells in heptamolybdate ion in water (c), molybdate ion in water (d), and $\mathrm{MoO}_{2}$ (e) is shown as a bold solid curve. Inverse Fourier transform spectrum for S10.2 ( $R$ range: 0.65-2.05 $\AA$ ) is shown as small circles of spectrum (b) in (A) with a fitted curve (bold) by assuming three Mo-O shells in heptamolybdate ion in water (c), molybdate ion in water (d), and $\mathrm{MoO}_{2}(\mathrm{e})$.

Figure 4 portrays XANES spectra of S8 (a), S10.1 (b) and S10.2 (c) with linear combination fitting (LCF) to the reference materials. High-quality XANES spectra were not obtained from other samples. Good fitting to the spectra of sediment samples was obtained by LCFs of three reference spectra of molybdate adsorbed on ferrihydrite, $\mathrm{MoO}_{2}$ and heptamolybdate, which are inferred from EXAFS analyses. The similar XANES spectra between aqueous $\mathrm{MoO}_{4}{ }^{2-}$ and that adsorbed on ferrihydrite, suggested that the contribution of molybdate adsorbed on ferrihydrite estimated by the LCF included aqueous $\mathrm{MoO}_{4}{ }^{2-}$ species and other adsorbed onto mineral phase. Similarity of XANES spectra was also found for aqueous heptamolybdate ion and hexaammonium heptamolybdate tetrahydrate (solid material), suggesting that successful fitting indicates the presence of a similar compound (e.g., outer sphere complex) in the solid phase for heptamolybdate species. The LCF showed that the most important Mo species in S10.2 was molybdate adsorbed on ferrihydrite (40\%) followed in order by heptamolybdate ( $35 \%$ ) and $\mathrm{MoO}_{2}(25 \%)$ (Table 3). S8 and S10.1 can be fitted by considering the same three Mo species. The most important species of S8 is molybdate adsorbed on ferrihydrite $(48 \%)$, followed in order by $\mathrm{MoO}_{2}(24 \%)$ and heptamolybdate (28\%), while contributions of $50 \%, 37 \%$ and $13 \%$ of the three species were estimated to S10.1, respectively (Table 3). 


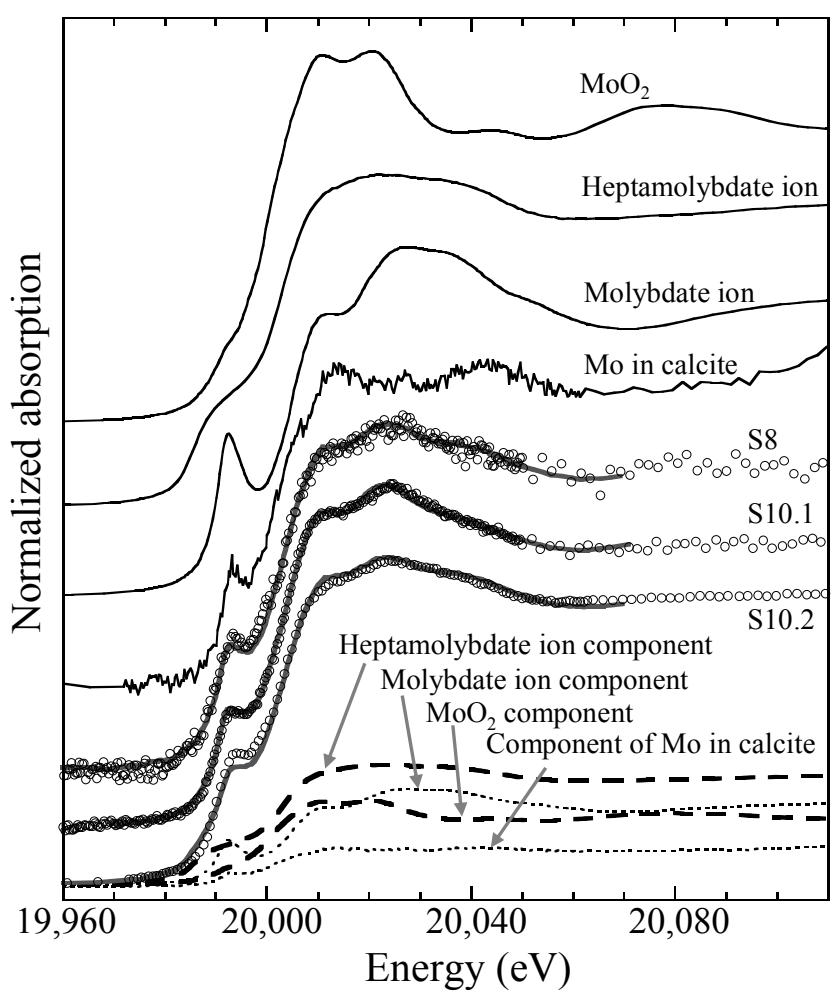

Figure 4. Mo K-edge XANES spectra for samples (S8, S10.1, and S10.2) and reference materials $\left(\mathrm{MoO}_{2}\right.$, heptamolybdate ion in water, molybdate ion in water, molybdate ion adsorbed on ferrihydrite and $\mathrm{MoS}_{2}$ ). Fitting results for the samples are shown as bold curves. Deconvolution results for S10.2 are given by showing the contributions of the three reference materials.

Table 3. Proportion of molybdate on ferrihydrite, heptamolybdate and $\mathrm{MoO}_{2}$ by Mo K-edge XANES.

\begin{tabular}{cccc}
\hline & Molybdate on Ferrihydrite (\%) & Heptamolybdate (\%) & $\mathbf{M o O}_{\mathbf{2}} \mathbf{( \% )}$ \\
\hline S8 & 48 & 28 & 24 \\
S10.1 & 50 & 13 & 37 \\
S10.2 & 40 & 35 & 25 \\
\hline
\end{tabular}

\section{Discussion}

\subsection{Characteristics of Water Chemistry in the Ponds and Rivers}

All the water was characterized as Ca-SO $\mathrm{S}_{4}$ type (Table 2). High concentrations of $\mathrm{SO}_{4}$ are most likely attributable to the oxidative dissolution of sulfides in the mining area. The very high concentration of $\mathrm{SO}_{4}$ in the secondary ponds was attributable to the dissolution of the waste rock dumped in the huge tailing pond. However, the Erdenet River, flowing from the upstream area, also exhibits high concentrations of $\mathrm{SO}_{4}$, which suggests that the $\mathrm{SO}_{4}$ production from sulfides occur not only from mining activity but also from natural processes in this area. The oxidative dissolution of sulfides usually engenders acid production [44]. The mining slags have been transported with wastewater to the tailing pond through the pipeline from the refinery factory. Prior to transport the wastewater through the pipeline, lime has been added to neutralize the acidity. High concentrations of $\mathrm{Ca}$ in the secondary ponds most likely derive from the lime treatment. The river waters also exhibit high Ca concentrations, which might be attributable to the natural neutralization of sulfuric acid by reaction with the calcite present in this area (Figure A1).

Concentrations of $\mathrm{Cu}$ in the river and pond waters were lower than $10 \mu \mathrm{g} / \mathrm{L}$, although the Erdenet mine produces $\mathrm{Cu}$ (Table 2). The lower concentrations of $\mathrm{Cu}$ are related to the artificially or naturally neutralized $\mathrm{pH}$. The dissolved $\mathrm{Cu}$ strongly adsorbs to mineral surfaces, especially for low crystalline 
iron oxides at neutral to alkaline conditions [45]. By contrast, the Mo concentrations in the river and ponds water were significantly higher than the average level in streams $(0.5 \mu \mathrm{g} / \mathrm{L},[8])$. The Mo concentrations of the secondary ponds exceed the level $(70 \mu \mathrm{g} / \mathrm{L})$ stipulated in WHO guidelines [10]. The high Mo concentration must be attributable to speciation of the Mo in the sediments, as discussed in the next section.

\subsection{Chemical Speciation of Mo in Sediments}

Results from sequential extraction revealed that most Mo is distributed in F1, F2, and F5. F5 is a fraction from total digestion after a four-step sequential procedure (Figure 2 and Table A1). It can be considered that Mo in F5 is immobile like the inside the matrix of the primary minerals or sulfides which remained after $\mathrm{H}_{2} \mathrm{O}_{2}$ treatment (F4). XANES and EXAFS spectra of all samples suggest the presence of $\mathrm{MoO}_{2}$. Mo in $\mathrm{MoO}_{2}$ takes tetrahedral coordination, which is the same as $\mathrm{Si}$ in $\mathrm{SiO}_{2}$ and $\mathrm{Al}$ in feldspar [46] and mica [36]. The $\mathrm{MoO}_{2}$ might represent the form of $\mathrm{Mo}(\mathrm{IV})$ in the primary minerals.

A large amount of Mo in S10.2 is distributed in the F1 (Figure A2). The contributions of Mo in F1 of S7 and S8 samples were found to be around 30\% of total Mo. The target of F1 is the Mo partitioning in exchangeable (weakly adsorbed) and calcium carbonates. Mo exists as molybdate anion in oxidizing surface conditions $[47,48]$. In neutral $\mathrm{pH}$ and oxic conditions, the chemical form of Mo(VI) is $\mathrm{MoO}_{4}{ }^{2-}[47,48]$. XANES analyses of all samples suggested the presence of molybdate adsorbed on ferrihydrite. Fe and Mn oxides have been documented as excellent scavengers of $\mathrm{MoO}_{4}{ }^{2-}[32,48,49]$. Molybdate adsorbs to Mn oxides as inner sphere complex in a form of distorted $\mathrm{Mo}(\mathrm{OH})_{6} \mathrm{complex}$, which is direct chemical bond sharing the surface oxygen [32]. On the other hand, it adsorbs to Fe oxides (ferrihydrite) as an outer sphere complex, which is a weak bonding form via electrostatic attraction [32]. Sequential extraction revealed that Mn from oxide forms (F2 and F3) are 40-900 mg/kg (Figure 2e and Table A1), whereas Fe from F2 and F3 are 3000-14,000 mg/kg (Figure 2d and Table A1). The amounts of Mn oxides in the sediments were markedly lower than Fe oxides in the sediments. XANES analyses suggest the presences of polymeric form molybdate (heptamolybdate). Spectroscopic studies have suggested that molybdate adsorbs to mineral surfaces not only as monomer, but also polymeric forms $[49,50]$. The heptamolybdate observed from EXAFS and XANES analyses might correspond to the polymeric adsorbed species.

F2 was an important Mo fraction from the sequential extraction. The target of F2 was Mo partitioning in poorly crystalline iron and manganese oxides. The reagent of $\mathrm{F} 2$ was oxalate solution at $\mathrm{pH} 3$, which enables the dissolution of poorly crystalline iron and manganese oxides. A significant amount of Mo is expected to be present as the outer spherically adsorbed form to ferrihydrite. The reagent of F1 was $1 \mathrm{M}$ acetate at $\mathrm{pH} 5$. The high concentration of acetate can be expected to replace the weakly adsorbed species. However, $\mathrm{MoO}_{4}{ }^{2-}$ is an anionic species. The adsorption of $\mathrm{MoO}_{4}{ }^{2-}$ on ferrihydrite is favored at lower $\mathrm{pH}$ conditions at around $\mathrm{pH} 5[32,48]$. Even in the presence of high concentration of acetate, some $\mathrm{MoO}_{4}{ }^{2}$ might remain in the ferrihydrite surfaces. Moreover, ferrihydrite occurred as nanoparticles that aggregate in the natural water [51]. The adsorbed $\mathrm{MoO}_{4}{ }^{2-}$ present inside the aggregates might only slightly access the external solutions in F1 treatment. We inferred that the Mo in F2 might also be attributable to the adsorbed $\mathrm{MoO}_{4}{ }^{2-}$ in the ferrihydrite.

\subsection{Solubility and Mobility of Mo in Erdenet Area}

The XAFS spectra of the sediment samples show that large amounts of Mo speciation in the rivers and ponds sediments are weakly adsorbed molybdate or polymeric molybdate on ferrihydrite. Sequential extraction shows that these Mo species are labile, which is consistent with XAFS results. It can be inferred that the pond and river sediments play a role as a secondary contamination source of Mo rather than as a sink of Mo in the area.

The weakly adsorbed molybdate can be desorbed from mineral surfaces in solution with high salt concentrations, as demonstrated in the F1 treatment from the sequential extraction (Figure 2a). The increase of salt concentrations in river and pond water by some artificial or natural processes might increase the 
release of Mo to solution. Change of $\mathrm{pH}$ in the pond and river waters can also occur by some artificial or natural processes. The lower $\mathrm{pH}$ engenders the increase of positive charge on ferrihydrite surfaces, especially in the presence of $\mathrm{SO}_{4}$ [52]. The negatively charged molybdate anion adsorbs favorably to a positively charged ferrihydrite surface at a low $\mathrm{pH}$ condition. By contrast, the increase of $\mathrm{pH}$ engenders the decrease of positive charge on ferrihydrite surfaces. Then, the adsorbed Mo must be released to the solution.

The surface sediments examined in present study will be in burial condition after the accumulation of sediments with time. Blanchard et al. [30] examined the post-depositional mobility of Mo in mine tailings. They showed that the adsorbed molybdate on ferrihydrite and ferrimolybdeite $\left(\mathrm{Fe}_{2}\left(\mathrm{MoO}_{4}\right)_{3} \cdot 8 \mathrm{H}_{2} \mathrm{O}\right)$ dissolves in burial condition. However, the dissolved $\mathrm{Mo}(\mathrm{VI})$ in the porewater effectively precipitates to form powellite $\left(\mathrm{CaMoO}_{4}\right)$ over time. The ponds and rivers from Erdenet area are also characterized to be high Ca concentration (Table 1). Therefore, the formation of powellite in burial condition possibly occurs in Erdenet area. Moreover, at more reducing conditions, the reduced $\mathrm{Mo}(\mathrm{IV})$ is expected to transform to molybdenum sulfide [53] because of the relatively high $\mathrm{SO}_{4}$ concentration in pond and river in the area. The solubilities of sulfides are low at reducing conditions [8]. Therefore, the mobility of Mo at the burial condition is possibly limited, but additional studies must be conducted to elucidate the post-depositional mobility of Mo in Erdenet area.

\section{Conclusions}

Waters collected from rivers and the ponds near the $\mathrm{Cu}-\mathrm{Mo}$ mining area in Erdenet city were characterized as neutral $\mathrm{pH}$ and $\mathrm{Ca}-\mathrm{SO}_{4}$ rich type. Although the concentrations of $\mathrm{Cu}$ in the rivers and ponds were low because of their neutral $\mathrm{pH}$, those of Mo were significantly higher than the world average. The Mo concentrations in the secondary ponds connected to the huge tailing pond exceed the level stipulated in $\mathrm{WHO}$ guidelines $(70 \mu \mathrm{g} / \mathrm{L})$.

The distribution of speciation of the Mo in the sediments was examined from five-step sequential extraction and XAFS. The XAFS spectra of the sediment samples revealed that high degrees of Mo speciation in the river and pond sediments are weakly adsorbed molybdate or polymeric molybdate on ferrihydrite. The sequential extraction consistently showed large amounts of Mo distributed in the labile fraction. Speciation of Mo in the surface sediments suggests that the pond and river sediments play a role as a secondary contamination source of Mo rather than as a sink of Mo in the area.

Author Contributions: T.S., K.F., O.A. and N.H. designed the fieldwork and analyses for water chemistry, sequential extraction and XRD. T.S., K.F., O.A., A.A., D.D., Y.A., I.E. and B.D. took samples and field measurements. Y.T. performed XAFS analysis. T.S., A.A. and G.B. conducted analyses for water chemistry, sequential extraction, and XRD. T.S., K.F., O.A. and N.H. wrote the paper.

Funding: Financial support was provided by the Higher Engineering Education Development Project, Functional material based on Mongolian Natural Minerals for Environmental Engineering, Cementitious and Float Process (No. J11A15), Biological Active Compounds and Useful Genes from Mongolian Plants, Microorganisms and their Application (No. J12A15), the Ministry of Education, Culture, Sports, Science, and Technology (MEXT) (No. JP17H06458), the Environmental Research Project (No. 163288) from the Sumitomo Foundation, the Department of Research and Innovation, National University of Mongolia and a cooperative research program of the Institute of Nature and Environmental Technology, Kanazawa University (Nos. 17039 and 18036).

Acknowledgments: The authors would like to thank J. Batkhuu, Department of Chemical and Biological Engineering, National University of Mongolia and Environmental Authority of Orkhon aimag in Erdenet city. This manuscript benefited from five anonymous reviewers. This work has been performed with the approval of SPring-8/JASRI (Proposal Nos. 2015A0118 and 2018A0148).

Conflicts of Interest: The authors declare no conflict of interest. 


\section{Appendix A}

Table A1. Concentrations of respective elements in each fraction after sequential extraction.

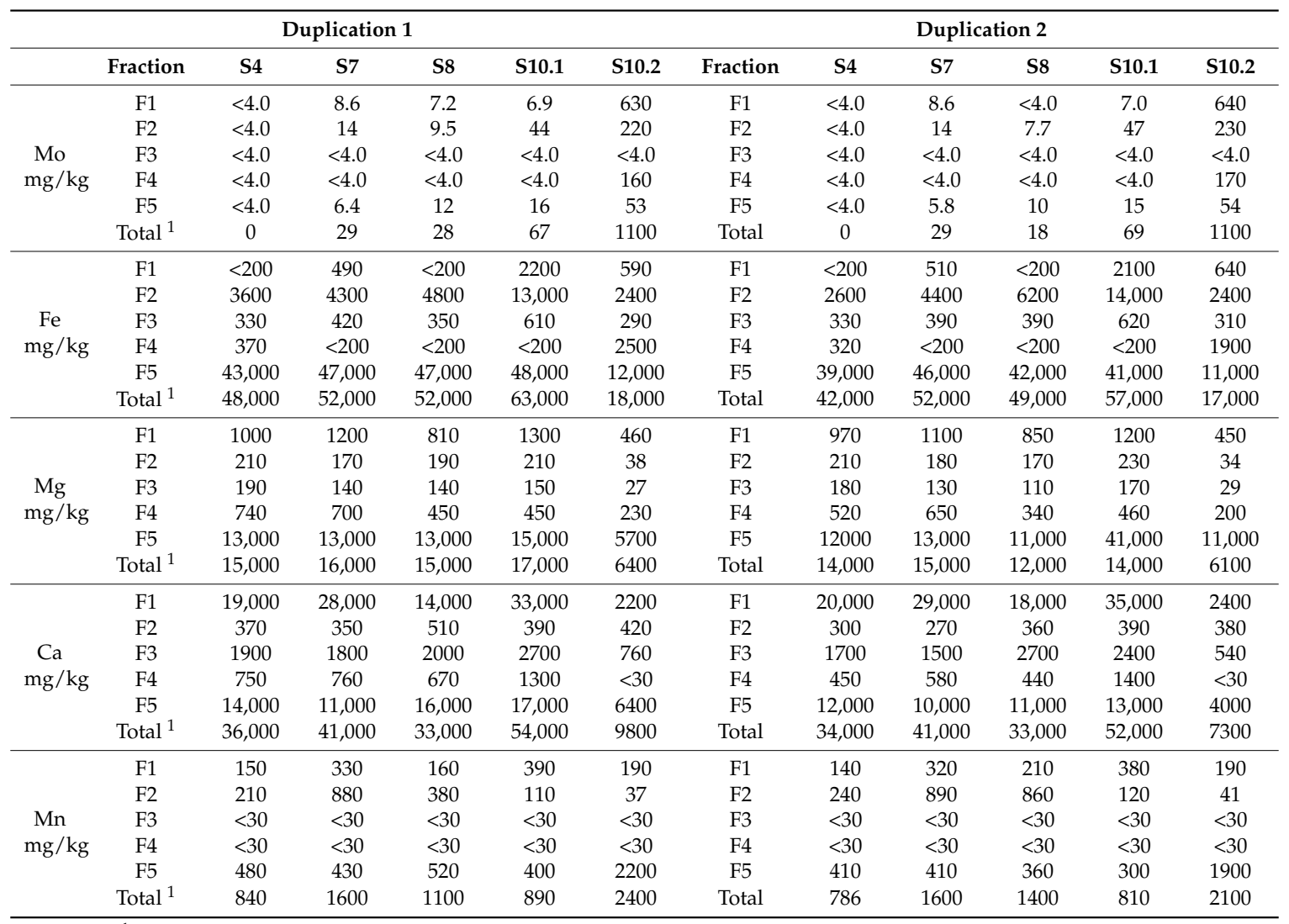

${ }^{1}$ Total concentrations were calculated by ignoring the concentrations with under the detection limits.

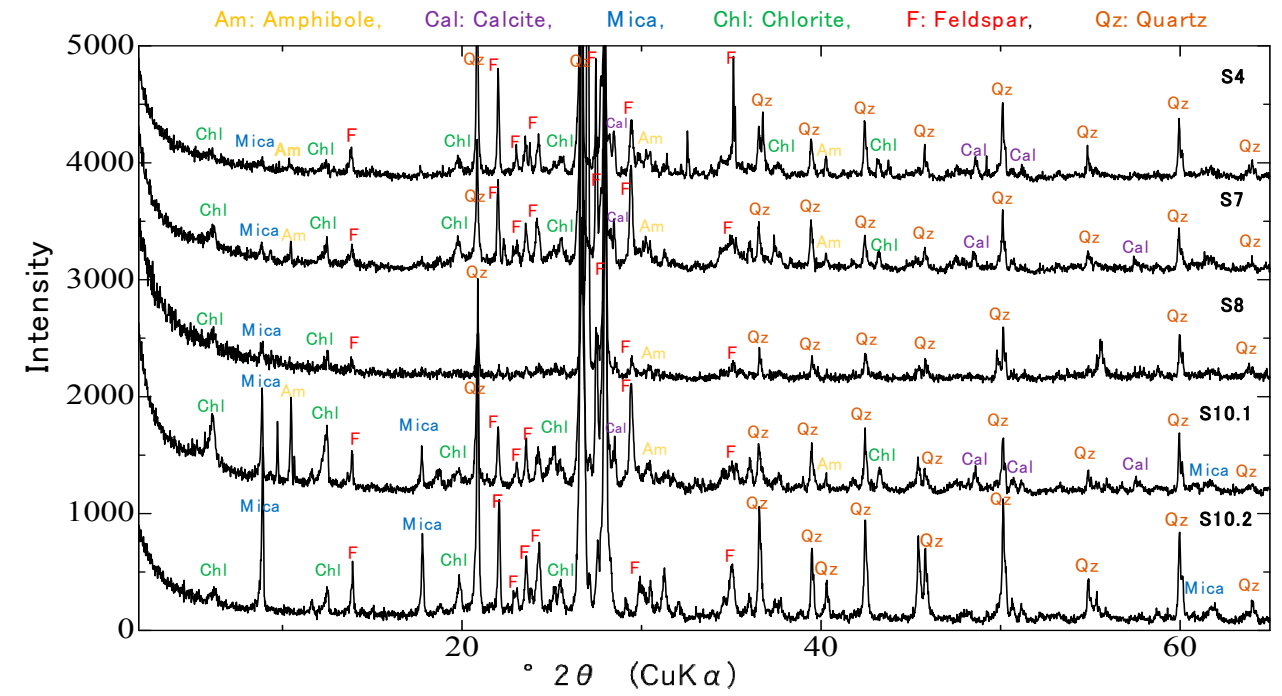

Figure A1. XRD patterns of the rivers (S4, Erdenet River; S7, Gavil River; and S8, Khangal River) and ponds (S10.1 and S10.2) sediment samples: Chl, chlorite; Mica, mica minerals; Am, amphibole; Cal, calcite; Qz, quartz; and F, feldspar. 

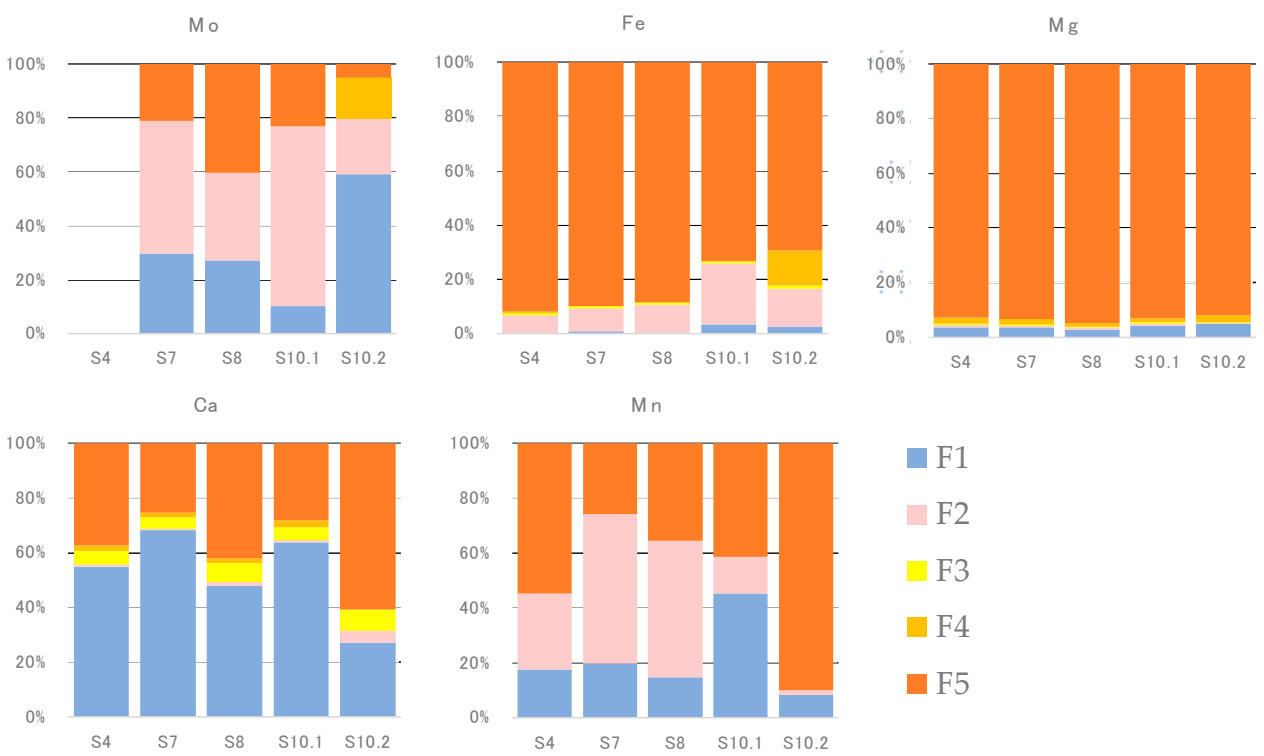

Figure A2. Results the sequential extraction of river (S4, Erdenet River; S7, Gavil River; and S8, Khangal River) and pond (S10.1 and S10.2) sediment samples for $\mathrm{Mo}, \mathrm{Fe}, \mathrm{Mg}, \mathrm{Ca}$, and $\mathrm{Mn}$ given in fraction.

\section{References}

1. España, J.S.; Pamo, E.L.; Santofimia, E.; Aduvire, O.; Reyes, J.; Barettino, D. Acid mine drainage in the Iberian Pyrite Belt (Odiel river watershed, Huelva, SW Spain): Geochemistry, mineralogy and environmental implications. Appl. Geochem. 2005, 20, 1320-1356. [CrossRef]

2. Fukushi, K.; Sasaki, M.; Sato, T.; Yanase, N.; Amano, H.; Ikeda, H. A natural attenuation of arsenic in drainage from an abandoned arsenic mine dump. Appl. Geochem. 2003, 18, 1267-1278. [CrossRef]

3. Shevenell, L.; Connors, K.A.; Henry, C.D. Controls on pit lake water quality at sixteen open-pit mines in Nevada. Appl. Geochem. 1999, 14, 669-687. [CrossRef]

4. World Bank. A Review of Environmental and Social Impacts in the Mining Sector; World Bank: Washington, DC, USA, 2006; p. 44.

5. Batsaikhan, B.; Kwon, J.S.; Kim, K.H.; Lee, Y.J.; Badarch, M.; Yun, S.T. Hydrochemical evaluation of the influences of mining activities on river water chemistry in central northern Mongolia. Environ. Sci. Pollut. Res. 2017, 24, 2019-2034. [CrossRef] [PubMed]

6. Battogtokh, B.; Lee, J.M.; Woo, N. Contamination of water and soil by the Erdenet copper-molybdenum mine in Mongolia. Environ. Earth Sci. 2014, 71, 3363-3374. [CrossRef]

7. Sotnikov, V.I.; Ponomarchuk, V.A.; Shevchenko, D.O.; Berzina, A.P. The Erdenetiyn-Ovoo porphyry Cu-Mo deposit, Northern Mongolia: 40Ar/39Ar geochronology and factors of large-scale mineralization. Geol. Geofiz. 2005, 46, 633-644.

8. Drever, J.I. The Geochemistry of Natural Waters: Surface and Groundwater, 3rd ed.; Prentice Hall: Upper Saddle River, NJ, USA, 1997.

9. Kisker, C.; Schindelin, H.; Rees, D.C. Molybdenum-cofactor-containing enzymes: Structure and mechanism. Ann. Rev. 1997, 66, 233-267.

10. WHO. Guidlines for Drinking Water Quality; WHO: Geneva, Switzerland, 2011.

11. Smedley, P.L.; Kinniburgh, D.G. Molybdenum in natural waters: A review of occurrence, distributions and controls. Appl. Geochem. 2017, 84, 387-432. [CrossRef]

12. Franscoli, F.; Hudson-Edwards, A. Geochemistry, mineralogy and microbiology of molybdenum in miningaffected environments. Minerals 2018, 8, 42. [CrossRef]

13. España, J.S.; Toril, E.G.; Pamo, E.L.; Amils, R.; Ercilla, M.D.; Pastor, E.S.; San Martín-Úriz, P. Biogeochemistry of a hyperacidic and ultraconcentrated pyrite leachate in San Telmo mine (Iberian Pyrite Belt, Spain). Water Air Soil Pollut. 2008, 194, 243-257. [CrossRef] 
14. Skierszkan, E.K.; Mayer, K.U.; Weis, D.; Beckie, R.D. Molybdenum and zinc stable isotope variation in mining waste rock drainage and waste rock at the Antamina mine, Peru. Sci. Total Environ. 2016, 550, 103-113. [CrossRef] [PubMed]

15. Smuda, J.; Dold, B.; Spangenberg, J.E.; Pfeifer, H.-R. Geochemistry and stable isotope composition of fresh alkaline porphyry copper tailings: Implications on sources and mobility of elements during transport and early stages of deposition. Chem. Geol. 2008, 256, 62-76. [CrossRef]

16. Alakangas, L.; Öhander, B.; Lundberg, A. Estimation of temporal changes in oxidation rates of sulphides in copper mine tailings at Laver, Northern Sweden. Sci. Total Environ. 2010, 408, 1386-1392. [CrossRef] [PubMed]

17. Huang, S.; Sillanpää, M.; Gjessing, E.T.; Peräniemi, S.; Vogt, R.D. Environmental impact of mining activities on the surface water quality in Tibet: Gyama valley. Sci. Total Environ. 2010, 408, 4177-4184. [CrossRef] [PubMed]

18. Khorasanipour, M.; Tangestani, M.H.; Naseh, R.; Majmohammadi, H. Hydrochemistry, mineralogy and chemical fractionation of mine and processing wastes associated with porphyry copper mines: A case study from the Sarcheshmeh mine, Iran. Appl. Geochem. 2011, 26, 714-730. [CrossRef]

19. Bilali, L.E.; Rasmussen, R.E.; Hall, G.E.M.; Fortin, D. Role of sediment composition in trace metal distribution in lake sediments. Appl. Geochem. 2002, 17, 1171-1181. [CrossRef]

20. Clemente, R.; Dickinson, N.M.; Lepp, N.W. Mobility of metals and metalloids in a multi-element contaminated soil 20 years after cessation of the pollution source activity. Environ. Pollut. 2008, 155, 254-261. [CrossRef] [PubMed]

21. Appelo, C.A.J.; Postma, D. Geochemistry, Groundwater and Pollution, 2nd ed.; CRC Press: Boca Raton, FL, USA, 2005.

22. Brown, G.E.; Foster, A.L.; Ostergren, J.D. Mineral surfaces and bioavailability of heavy metals: A molecularscale perspective. In Geology, Mineralogy, and Human Welfare; National Academy of Sciences colloquium, Arnold and Mabel Beckman Center: Irvine, CA, USA, 1999.

23. Takahashi, Y.; Fan, Q.; Suga, H.; Tanaka, K.; Sakaguchi, A.; Takeichi, Y.; Ono, K.; Mase, K.; Kato, K.; Kanivets, V.V. Comparison of solid-water partitions of radiocesium in river waters in Fukushima and Chernobyl Areas. Sci. Rep. 2017, 7, 12407. [CrossRef] [PubMed]

24. Harada, T.; Takahashia, Y. Origin of the difference in the distribution behavior of tellurium and selenium in a soil-water system. Geochim. Cosmochim. Acta 2008, 72, 1281-1294. [CrossRef]

25. Gomes, A.F.S.; Lopez, D.L.; Ladeira, A.C.Q. Characterization and assessment of chemical modifications of metal-bearing sludges arising from unsuitable disposal. J. Hazard. Mater. 2012, 199-200, 418-425. [CrossRef] [PubMed]

26. Yanase, N.; Nightingale, T.; Payne, T.; Duerden, P. Uranium distribution in mineral phases of rock by sequential extraction procedure. Radiochim. Acta 1991, 52-53, 387-393. [CrossRef]

27. Žemberyová, B.; Barteková, J.; Hagarová, I. The utilization of modified BCR three-step sequential extraction procedure for the fractionation of $\mathrm{Cd}, \mathrm{Cr}, \mathrm{Cu}, \mathrm{Ni}, \mathrm{Pb}$ and $\mathrm{Zn}$ in soil reference materials of different origins. Talanta 2006, 70, 973-978. [CrossRef] [PubMed]

28. Favas, P.J.C.; Pratas, J.; Gomes, M.E.P.; Cala, V. Selective chemical extraction of heavy metals in tailings and soils contaminated by mining activity: Environmental implications. J. Geochem. Explor. 2011, 111, 160-171. [CrossRef]

29. Qin, H.B.; Takeichi, Y.; Nitani, H.; Terada, Y.; Takahashi, Y. Tellurium distribution and speciation in contaminated soils from abandoned mine tailings: Comparison with selenium. Environ. Sci. Technol. 2017, 51, 6027-6035. [CrossRef] [PubMed]

30. Blanchard, P.E.R.; Hayes, J.R.; Grosvenor, A.P. Investigating the geochemical model for molybdenum mineraliation in the JEB tailings management facility at McClean Lake, Saskatchewan: An X-ray absorption spectroscopy study. Environ. Sci. Technol. 2015, 49, 6504-6509. [CrossRef] [PubMed]

31. Kavalieris, I.; Khashgerel, B.E.; Morgan, L.E.; Undrakhtamir, A.; Borohul, A. Characteristics and 40Ar/39Ar geochronology of the Erdenet Cu-Mo deposit, Mongolia. Econ. Geol. 2017, 112, 1033-1053. [CrossRef]

32. Kashiwabara, T.; Takahashi, Y.; Tanimizu, M.; Usui, A. Molecular-scale mechanisms of distribution and isotopic fractionation of molybdenum between seawater and ferromanganese oxides. Geochim. Cosmochim. Acta 2011, 75, 5762-5784. [CrossRef] 
33. Schwertmann, U.; Cornell, R.M. Iron Oxides in the Laboratory: Preparation and Characterization; VCH: Vancouver, BC, Canada, 1991.

34. Rodríguez, L.; Ruiz, E.; Alonso-Azcárate, J.; Rincón, J. Heavy metal distribution and chemical speciation in tailings and soils around a Pb-Zn mine in Spain. J. Environ. Manag. 2009, 90, 1106-1116. [CrossRef] [PubMed]

35. Zabinsky, S.I.; Rehr, J.J.; Ankudinov, A.; Albers, R.C.; Eller, M. Multiple-scattering calculations of X-ray-absorption spectra. Phys. Rev. B 1995, 52, 2995-3009. [CrossRef]

36. Bailey, S.W. Classification and structures of the micas. Rev. Mineral. Geochem. 1984, 13, 1-12.

37. Bailey, S.W. Chlorites: Structures and crystal chemistry: In hydrous phyllosilicates (Exclusive of Micas). Rev. Mineral. 1988, 19, 347-403.

38. Cornell, M.; Schwertmann, U. The Iron Oxides: Structure, Properties, Reactions, Occurences and Uses, 2nd ed.; VCH: Vancouver, BC, Canada, 2004.

39. Busenberg, E.; Plummer, L.N. Thermodynamics of magnesian calcite solid-solutions at $25^{\circ} \mathrm{C}$ and 1 atm total pressure. Geochim. Cosmochim. Acta 1989, 53, 1189-1208. [CrossRef]

40. O'Day, P.A.; Rehr, J.J.; Zabinsky, S.I.; Brown, G.E.J. Extended X-ray absorption fine structure (EXAFS) analysis of disorder and multiple-scattering in complex crystalline solids. J. Am. Chem. Soc. 1994, 116, 2938-2949. [CrossRef]

41. Capitelli, F.; Selim, M.D.; Mukherjea, K.K. Synthesis and crystal structure determination of sodium molybdate dihydrate. Asian J. Chem. 2006, 18, 2856-2860.

42. Evans, H.T.; Gatehouse, M.B.; Leverett, P. Crystal structure of the heptamolybdate(VI) (paramolybdate) ion, $\left[\mathrm{Mo}_{7} \mathrm{O}_{24}\right]^{6-}$, in the ammonium and potassium tetrahydrate salts. J. Chem. Soc. Dalton Trans. 1975, 6, 505-514. [CrossRef]

43. Bolzan, A.A.; Kennedy, B.J.; Howard, C.J. Neutron Powder diffraction study of molybdenum and tungsten dioxides. Aust. J. Chem. 1995, 48, 1473-1477. [CrossRef]

44. Akcil, A.; Koldas, S. Acid mine drainage (AMD): Causes, treatment and case studies. J. Clean. Prod. 2006, 14, 1139-1145. [CrossRef]

45. Webster, J.G.; Swedlund, P.J.; Webster, K.S. Trace metal adsorption onto an acid mine drainage iron(III) oxy hydroxy sulfate. Environ. Sci. Technol. 1998, 32, 1361-1368. [CrossRef]

46. Ribbe, P.H. Chemistry, structure, and nomenclature of feldspars. Rev. Mineral. 1975, 2, 1-12.

47. Goldberg, S.; Johnston, C.T.; Suarez, D.L.; Lesch, S.M. Mechanism of molybdenum adsorption on soils and soil minerals evaluated using vibrational spectroscopy and surface complexation modeling. Dev. Earth Environ. Sci. 2007, 7, 235-266.

48. Gustafsson, J.P. Modelling molybdate and tungstate adsorption to ferrihydrite. Chem. Geol. 2003, 200, 105-115. [CrossRef]

49. Arai, Y. X-ray absorption spectroscopic investigation of molybdenum multinuclear sorption mechanism at the goethite-water interface. Environ. Sci. Technol. 2010, 44, 8491-8496. [CrossRef] [PubMed]

50. Davantès, A.; Lefèvre, G. In situ characterization of (poly)molybdate and (poly)tungstate ions sorbed onto iron (hydr)oxides by ATR-FTIR spectroscopy. Eur. Phys. J. Spec. Top. 2015, 224, 1977-1983. [CrossRef]

51. Tsubaki, H.; Saito, T.; Murakami, T. Size distribution of ferrihydrite aggregate and its implication for metal adsorption and transport. J. Mineral. Petrol. Sci. 2012, 107, 244-249. [CrossRef]

52. Fukushi, K.; Aoyama, K.; Yang, C.; Kitadai, N.; Nakashima, S. Surface complexation modeling for sulfate adsorption on ferrihydrite consistent with in situ infrared spectroscopic observations. Appl. Geochem. 2013, 36, 92-103. [CrossRef]

53. Dahl, T.W.; Chappaz, A.; Fitts, J.P.; Lyons, T.W. Molybdenum reduction in a sulfidic lake: Evidence from X-ray absorption fine-structure spectroscopy and implications for the Mo paleoproxy. Geochim. Cosmochim. Acta 2013, 103, 213-231. [CrossRef]

(C) 2018 by the authors. Licensee MDPI, Basel, Switzerland. This article is an open access article distributed under the terms and conditions of the Creative Commons Attribution (CC BY) license (http:/ / creativecommons.org/licenses/by/4.0/). 